\title{
Secondary Supratentorial Anaplastic Astrocytoma
}

National Cancer Institute

\section{Source}

National Cancer Institute. Secondary Supratentorial Anaplastic Astrocytoma. NCI

Thesaurus. Code C5416.

An anaplastic astrocytoma occurring in the supratentorial area secondary to a

preexisting tumor. 